\title{
The house of the rising sun medical school
}

M edicine is an old profession. One of the principal aspects of its practice is that expert advice is freely given to the one who suffers and asks for help. When the practice is faithful to its essence, there is no conditional relation between the service rendered and compensation in the form of a reasonable fee. As with the practice of medicine, the roots of that practice, its schools of medicine, are also open and publicly accessible. They cannot be bought. Or rented. Selling them or their names does not make logical sense, and it does present considerable reputational and ethical risk. ${ }^{1}$ Medical schools, like the universities that house them, are public institutions created for the public good. To be sure, some of our best universities were founded on the legacies of wealthy men and women, and these schools will bear their benefactors' names forever. But that money was given in perpetuity, without let or hinder, save only that it be used for the general public good of the advancement of learning. Most universities have since become dependent on public funding.

In recent years, a number of our medical and other health care schools have allowed private donors to have their names placed before that of the school. There may be a proviso that the donation be used for a donor-specified purpose. Although these donations are typically substantial (the median amount in 15 American transactions was US\$ 95 million $^{1}$ ), the fact rather than the amount is what is important. At best, this proposition is imprudent; at worst, it risks perverting the mission of a medical school. Like the science upon which modern medical practice depends, a medical school must be free to pursue its mission and direction without nonscientific interference. The knowledge base of a medical school is oriented to practise on the form and function of our fearfully and wonderfully made body, and the thousands of ways it can become ill and be made well again. But advancing that knowledge base is a matter of pure and applied science. Finding new ways to

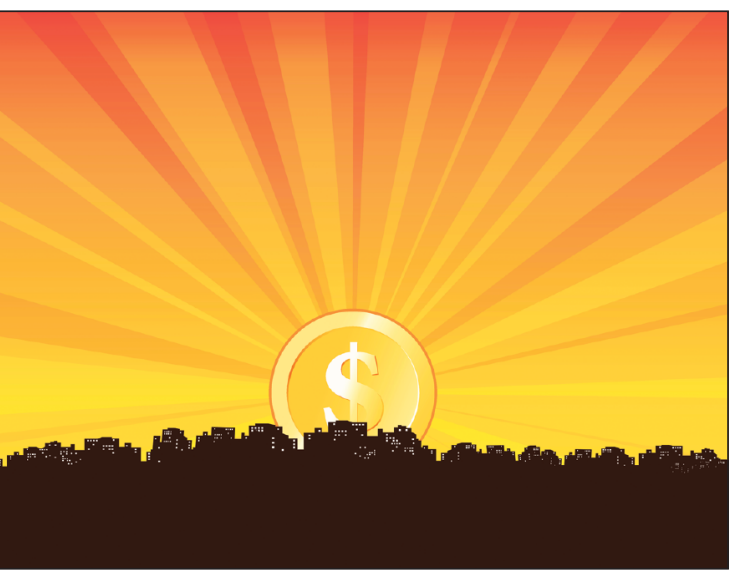

treat miserable diseases only works when medical researchers are free to be indomitable. Practitioners render correct diagnoses when they are free to be curious and skeptical. Within institutions with such freedoms, there is plenty of room for public funding, public or private research grants and building projects. But the last thing medicine needs is influence purchased by captains of industry. Even when the gift is unconditional, the medical school is associating itself with the reputation of the donor; even when it is anonymous, the school lends the potential for influence when it should not. Experience shows that donation money is sometimes obtained from less than admirable financial activity. ${ }^{1}$ It is also important to remember that gifts are typically accompanied by a substantial public subsidy in the form of tax avoidance. While the public purse realizes a loss, the private donor is edified.

Imagining that an institution as ethical as a medical school can be sold, is to consider a form of prostitution (in its sense of crass mercantilism). Though an individual may choose to sell the body, often to transform a destitute predicament into a more livable one, few of us would agree to sell our name. Indeed, many of us expend much time and money to protect or defend our good name. In much the same way, the name of a medical school is deeply associated with its identity and its contribution to its university and city and far beyond.

When they sell the name, those in charge of the medical school behave as though that name were theirs to sell. As if they own it. Well they don't. Because no one should own medical schools. Because everyone owns them. They are by their very nature not for sale. Not now. Not ever.

\section{Ken Flegel MDCM MSc}

Senior Editor

CMAJ

\section{References}

1. Loeffler JS, Halperin EC. Selling a medical school's name: ethical and practical dilemmas. JAMA 2008;300:1937-8.

CMAJ 2014. DOI:10.1503/cmaj.121784 